\title{
Liberal International Relations Theory and the Military
}

\author{
Scott A. Silverstone
}

\section{Contents}

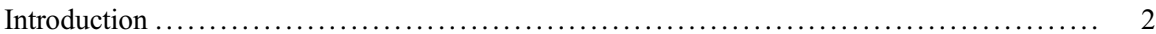

Liberal International Relations Theory and the Philosophy of Science $\ldots \ldots \ldots \ldots \ldots \ldots \ldots \ldots, \quad 3$

Alternative Forms of Liberal International Relations Theory $\ldots \ldots \ldots \ldots \ldots \ldots \ldots \ldots \ldots \ldots, 4$

Liberal International Relations Theory in Practice .................................. 9

Summary: Liberal International Relations Theory in an Era of Renewed Great Power

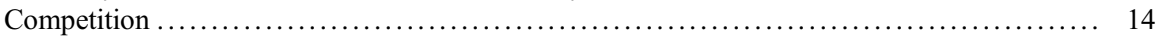

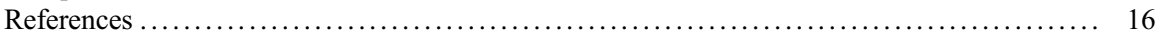

\section{Abstract}

While much of the study and practice of international relations is anchored in the centuries-old tradition of realism, this chapter explores the important contributions that another theoretical tradition, liberalism, has made to the study of international security and the role of military power. Emerging from Enlightenment beliefs about the rationality of individuals and the potential for progress in human affairs, liberal theories and policy ideas have focused on offering alternative means for states seeking security, alternatives that might break the endless competition and warfare that realists see as inevitable in an anarchic world. Liberal theories emphasize how rules and institutions can help self-interested states achieve mutual interests, they see economic interdependence as a potent incentive for states to avoid war, and they argue that democracies enjoy more peaceful relations with other democracies. The chapter traces the history of liberal international relations theory as it matured in response to the mass violence and chaos of the twentieth century, and it examines a number of examples - like European integration, the post-World War II global economic order, and the control of nuclear weapons - to showcase how liberal ideas in practice might reduce the dangers of war and enhance the prospects for global cooperation.

S. A. Silverstone ( $\bowtie)$

United States Military Academy at West Point, West Point, NY, USA

e-mail: Scott.Silverstone@westpoint.edu 


\section{Keywords}

Liberalism - International relations theory $\cdot$ Military force $\cdot$ Power $\cdot$ War Institutions $\cdot$ Economic interdependence $\cdot$ Democratic peace

\section{Introduction}

In the field of international relations, most scholars acknowledge that the realist tradition, with its pessimistic claims about human nature, the relentless and often violent struggle for security and power, and the inherently competitive character of international anarchy, remains the dominant approach in the study of state behavior. Realists claim a heritage reaching back to the venerable ancient Greek historian Thucydides (460-400 B.C.) and his chronicle of the Peloponnesian War in the fifth century BCE, as well as such foundational political philosophers as Niccolò Machiavelli and Thomas Hobbes (Schmidt, 2021). With its fixation on the inescapable potential for violent conflict among states, realist international relations theory seems tailor-made for understanding the role of military power in world politics and the military as a state institution.

Even though much of the study and practice of international relations is anchored in this centuries-old tradition, another western philosophical tradition, liberalism, has made important contributions to the study of security and the role of military power as well. Liberalism can also claim a heritage that reaches back at least to the Enlightenment period of the eighteenth century, when the spirit of rationalism, scientific inquiry, and a belief in the potential for human progress came to dominate the intellectual climate. In recent decades, specific theories within the liberal tradition, as well as liberal ideas at work in actual world politics, have enjoyed increasing prominence. This is true for liberalism as both an ontological framework (its claims about how the world works) for explaining state behavior and as a source of teleological promise (the goals we can achieve by studying international relations) as we search for policy solutions that might reduce threats and control the dangerous implications of international anarchy and military competition.

The purpose of this chapter is to explain what liberal international relations theory offers for understanding international security and military power. The next section frames liberalism with the key elements of the philosophy of science to explain how this tradition understands human nature and behavior, how it treats the character of the international system and state relations, how it conceptualizes power and the role of military force, and its essentially progressive orientation toward the human experience (Sookermany, 2021). This will set the stage for an assessment of different variants of liberal international relations theory and a discussion of specific examples of liberal theory in practice that range from the early twentieth century to the present, with direct relevance to military force in world politics. 


\section{Liberal International Relations Theory and the Philosophy of Science}

In many ways, liberalism can be considered a challenge to the dark vision presented by realists. It is an ontology that offers an alternative way to conceive of human nature and the possibilities for overcoming the most competitive and destructive aspects of state behavior. In fact, Enlightenment beliefs about the rationality of individuals and the potential for progress in human affairs have been a primary motivation behind liberalism for centuries, as successive generations struggled with the problems of repressive government, poverty, and the increasingly destructive character of warfare. This was particularly true after World War I and World War II, which showcased the immense scale of violence now possible in the industrial and nuclear age. Most liberals after World War II did not dismiss the core realist claim that humans are often driven by fear, insecurity, distrust, or the quest for power. Nor could they ignore what seemed like a historical reality that states appeared to be locked in cycles of competition and warfare, particularly as the two world wars were followed quickly by a new Cold War and the existential threat of an accelerating nuclear arms race. Despite the mass violence and dangers of military competition of the twentieth century, the liberal worldview simply denied that this was inevitable. And drawing from a positivist epistemology (which studies international relations to discover objective insights), liberals have sought ways to understand how states can, and do, break the cycle of competition and violence that realists seem resigned to.

Interestingly, one of the greatest critics of liberal international relations theory of the twentieth century, the British historian E. H. Carr (who derisively referred to it as "utopianism"), ultimately argued that realism alone is "barren," and that it leads to the "sterilization of thought." It forces humans, he argued, to simply adapt to the realities of seemingly irresistible forces at work in the world, while providing no plan of action or larger purpose to change the worst traits of human behavior. Carr asserted, however, that "such a conclusion is plainly repugnant to the most deepseated belief of man about himself. That human affairs can be directed and modified by human action and human thought... The human will," he believed, "will continue to seek an escape from the logical consequences of realism" (Carr, 1964, p. 10, 92-93). It is this effort to direct and modify human action and thought that liberal scholars and policy practitioners have taken most seriously, and which distinguish them most clearly from realists.

Like realism, liberalism is based on a set of logically connected assumptions that can form the basis of specific liberal theories. Most importantly, liberals contend that humans are rational and self-interested actors. This is obviously an assumption shared by realists. Unlike realists, however, liberals contend that individuals and the states they lead can achieve these self-interests, to include security and prosperity, through cooperation with other states. While realists argue that states exist in a zero-sum world - in which a gain for one state must come at the expense of another liberals argue that states can seek mutual interests with other states, even as they coexist in an anarchical international system. That is, states can discover ways to better achieve their own security and prosperity by coordinating their behavior rather 
than perpetually competing against one another. An important supporting assumption is that humans are capable of learning from mistakes and successes, have choice in how they pursue their interests, and can adjust their behavior if they discover that competition only leads to greater dangers and less prosperity. Learning and change in behavior are the root of human progress.

It is important to emphasize that liberals do not ignore the security imperative that realists focus on. This is clear in the writings of prominent early liberal philosophers such as John Locke, who argued that security from violent death must be the first priority of any political actor. Without physical security, no other human aspirations are possible. What liberals stress, however, is that it is possible to maximize security, not by accumulating more military and economic hard power than others, but through alternative means. American President Woodrow Wilson made this point at the end of World War I. What form of security did the balance of power system provide, he asked, when reviewing the tragic loss of 15 million lives and the ruin spread across much of Europe? The balance of power, Wilson argued, was bankrupt as a means to achieve security; it only magnified insecurity and could not prevent this horrible war (Wilson, 1923). While many realists would throw up their hands believing that a balance of power system was the best states were capable of to achieve security, President Wilson argued that humans could be enlightened enough to create a new cooperative system to achieve a more stable and lasting peace without great power war.

\section{Alternative Forms of Liberal International Relations Theory}

While liberals over the past centuries would all tend to share these ontological and teleological assumptions about human behavior, international relations, and security, Michael Doyle points out that there is "no canonical description of liberalism" (Doyle, 1986, p. 1152). In other words, there is no single, definitive version of the liberal worldview. Robert Keohane notes that there are three basic types of liberal theories: republican, commercial, and regulatory (Keohane, 1990, p. 176-182). All share a positivist epistemology and research methodologies, and all have direct implications for the role of military force in international security.

The oldest version of liberal international relations theory is republican security theory, which has its roots in both ancient Greek and Roman political philosophy (Deudney, 2007). The main claim here is that the way in which a state's government is organized will influence how it behaves internationally. Specifically, republican institutions, such as democratic representation and political checks and balances among different parts of the government, are said to constrain the use of military force. In the Enlightenment period, this argument was advanced first by the American founders, who believed that the federal character of the American republic would make it less war prone (Jay, 1787; Madison, 1787; Silverstone, 2004), and by the German philosopher Immanuel Kant, who argued that the cause of "perpetual peace" would be best served by a "pacific union" among republican states that agreed to a peaceful order among themselves (Kant 1970, p. 100-101). In recent 
decades, international relations scholars have called this the "Democratic Peace" and have studied the claim that democracies will not fight wars with other democracies, and that an international system with more democracies will produce a more peaceful world (Brown, Lynn-Jones, \& Miller, 1996).

The logic of Democratic Peace theory presents two causal mechanisms said to produce this outcome. The first focuses on domestic political institutions: When engaged in a dispute that could escalate to war, the domestic political checks and balances and electoral accountability will constrain each democracy and make it easier to resolve the dispute without resorting to military force. The second causal mechanism focuses on a normative or cultural explanation for democratic peace. According to this argument, democracies recognize that other democracies share common political identities and beliefs that favor nonviolent conflict resolution, and as a result, the citizens and leadership of democratic states simply refuse to act violently against another democracy (Russett, 1993).

Of course, there is another side to this argument. Some scholars point out that the same liberal norms and identities that might keep the peace among democratic states can increase the likelihood or intensity of conflict with nondemocratic states. Michael Doyle notes that "liberalism is not inherently 'peace-loving'; nor is it consistently restrained or peaceful in intent" (Doyle, 1983a, p. 206). When facing nonliberal states, he argues, liberal states will often raise "conflicts of interest into crusades." Against weak nonliberal states that are judged to lack normative or moral legitimacy because of their repressive characteristics and behavior, liberal states are tempted to launch "imperial interventions" (Doyle, 1983b, p. 324). In the current era, it is easy to observe how the increasing hostility and competitive character of America's relationship with both Russia and China is not merely a result of the mutual fears and uncertainties of an anarchic international system. The liberal impulse to challenge nonliberal states over their human rights records and repression of political rights and freedoms intensifies the antagonism and hostility in ways that decisively shape security relations.

The second form of liberal theory in Keohane's typology is commercial or economic liberalism. As the name implies, this form of liberalism looks to trade as a potent form of cooperation that makes war less likely. Among the Enlightenment liberal philosophers, Montesquieu was the first to make this claim, arguing that "the natural effect of commerce is to lead to peace. Two nations that trade together become mutually dependent if one has an interest in buying, the other has an interest in selling; and all unions are based on mutual needs" (Hirschman, 1977, p. 80). Since war also destroys trade relations among belligerent states, modern liberal scholars see the preservation of trade and financial ties as a strong incentive for rivals to exercise restraint, so their disputes do not tip into violent conflict (Rosecrance, 1986; Copeland, 1996, p. 5-11).

In the contemporary era, the most successful example of using economic interdependence to promote peace among rival states has been the European Union, which we will discuss in more detail below. More recently, perhaps the most important application of economic liberalism is in the debate over how the continuing growth of Chinese economic, political, and military power will impact 
the prospects for war and peace in the coming decades. As realist scholars point out, shifting power among major states in the international system tends to produce dangerous periods of uncertainty and fear over whether the rising power will use its growing capabilities in an aggressive way. Uncertainty and fear currently dominate American perceptions of the rise of China, while increasing militarized antagonism between China and Taiwan, and China and Japan lead many to worry about the risk that this antagonism could lead to war. But all parties also recognize that because of the deep commercial and financial ties among these states, one of the costs of war would be a terrible blow to their economies. Potential economic costs might then be one incentive, among several, for China, the United States, Taiwan, and Japan, to hold military competition below the threshold of armed conflict. In fact, this logic was central to American President Bill Clinton's efforts to admit China into the World Trade Organization in the 1990s (Ikenberry, 2008; Tang, 2021).

In a way, commercial liberalism can be considered one form of the third type of liberal international relations theory in Keohane's typology: regulatory liberalism. Regulatory liberalism is based on the simple claim that states can best pursue their mutual interests in many different areas of international life - such as security, economic growth, environmental protection, health, and social welfare - by creating rules to guide their behavior, rules that facilitate cooperation and increase trust and that help in the sharing of information and resources and in the adjudication of disputes. The most common term used to describe this type of liberal approach is "institutionalism" (or in earlier work, "regime theory"), which captures the important fact that states can create sets of rules, formal and informal, that define appropriate behavior, rules that set out the rights actors should enjoy and the obligations they should assume in how they behave and treat others. This is the essence of what social institutions are (Keohane, 1983; Keohane, 1998; North, 1990).

Keohane makes two important points about states' efforts to regulate their interaction through rules. First, authoritarian as well as democratic states can take part in this effort. While the republican, or democratic peace, version of liberalism has been prominent in international relations theory since the end of the Cold War, it is the most restrictive in scope because it only applies to the behavior of democratic states. But assuming that authoritarian states are rational actors, "Neoliberal Institutionalists" propose that nondemocratic states of various kinds are capable of recognizing that they might maximize their interests through "mutually beneficial agreements" with other states, just as well as democracies can (Keohane, 1990, p. 180). Second, the effort to discover mutual interests and develop rules to regulate cooperative interaction is not an easy task. While liberals do not accept the realist notion that anarchy necessarily produces competitive state behavior, they do accept that the lack of enforcement of agreements in world politics makes states wary of being cheated. Also, cooperation through rules means that states must voluntarily accept limits on their behavior, which might be difficult to do. Sometimes the temptation to cheat is too strong for sustained cooperation (Axelrod, 1984).

Despite these incentives to avoid cooperation, according to neoliberal institutionalists, if states calculate that their interests are still better met through cooperation than through rejection of cooperation, the basis for regulated behavior exists. 
Perhaps the most potent rationale for playing by the rules in this rationalist ontology is what institutionalists call "reciprocity." Simply put, it is the calculation that if I play by the rules, other states are more likely to play by the rules, which makes me better off. But if I break the rules, then other states will reciprocate by breaking the rules too, and I will lose the benefits of cooperation that help me achieve our state's goals across a range of issue areas.

In recent decades, these three versions of liberal international relations theory democratic peace, economic liberalism, and institutionalism - have been most prominent in the research conducted by scholars working in this tradition. But each reflects the concept of "interdependence," first introduced to liberalism by European scholars in the late nineteenth and early twentieth centuries, and further developed by Keohane and Nye in the 1970s. Their work captured changes in the character of domestic and world politics that scholars and policy practitioners were observing. Keohane and Nye called it "complex interdependence," and it was a direct challenge to realist theory's claims (as discussed in the introductory chapter of this book section and in the chapter on realist theory) about the state as a unitary actor, the priority given to security and power in interstate relations, and whether nonstate actors play an important independent role in international politics (Rønnfeldt, 2021; Schmidt, 2021).

The complex interdependence paradigm rests on three basic premises. First, "multiple channels connect societies." While states might still occupy the dominant position in world politics, nongovernmental interest groups and corporate actors develop "transnational" links with counterparts around the world, thereby making their governments' policies "more sensitive" to these interests in other countries. Second, "foreign affairs agendas" are no longer dominated by a clear "hierarchy among issues." Instead, military security is one of many issues that governments feel compelled to prioritize. Henry Kissinger, Secretary of State under Presidents Nixon and Ford and among the realist elites in American foreign policy, once noted that "the problems of energy, resources, environment, population, the uses of space and seas now rank with questions of military security... which have traditionally made up the diplomatic agenda" (Keohane \& Nye, 2012, p. 20-22).

The third premise in the complex interdependence paradigm is that military force does not necessarily provide the most important source of power in world politics. It is important to note what Keohane and Nye admit: This logic works best among industrialized, pluralistic countries whose societies are linked by multiple webs of interdependence. These countries enjoy a wider "margin of safety" for their physical security with each other, and as a result, they can downplay the role of military power without assuming the security risks that realists warn about. While complex interdependence might not work among many pairs of states in the international system, it is still a radical development in world politics when put in historical perspective: The community of industrialized, pluralistic countries includes most of the major powers that in earlier centuries suffered from cycles of massive armed conflict (Keohane \& Nye, 2012, p. 22-24).

Other scholars emphasize that liberals make different assumptions about the nature of states. While realists tend to treat the state as a unitary actor, liberals 
point out that states are composed of a variety of domestic social actors (individuals, groups, and coalitions) that see the governmental apparatus of the state as a "transmission belt" for a variety of preferences they would like the state to pursue through its foreign policy (Moravcsik, 2008). These societal preferences can impact how the state perceives threats and identifies friends and adversaries. Social preferences might also set policy priorities that place demands on the state's military forces that go beyond the need to provide basic national defense. Such new demands could include support for humanitarian intervention operations abroad, efforts to rescue "failing" states or those suffering from civil conflict. Citizens might demand that their military personnel will respect international law and ethics in the use of force, demand that the state respond to the plight of international refugees and ecological crisis, or provide natural disaster relief.

One of the early proponents of the complex interdependence paradigm, Joseph Nye, has also been a leading liberal voice challenging the realist assumptions about power in world politics. It seems that all intellectual approaches in the field of international relations recognize that the concept of power is central to social life at all levels, and that it defines political life in particular. For realists, what really matters is the so-called hard power that a state can mobilize in support of its security. Hard power includes those material resources that contribute directly to the state's ability to physically defend itself from others' aggression or to ward off their threats. Hard power might deter others' aggressive intentions through the threat of painful retaliation or provide the tools to compel others to do what we want, either through the mere threat of pain or the delivery of pain. This is captured by what Thomas Schelling (1977) once called "the power to hurt." Military power is paramount, but it is supported by other hard power resources that underwrite war potential, like economic assets, the state's territory and population, and its natural resource base.

Nye (2011, p. 10-13) proposes that power in international politics is more complex. Hard power matters, but it fails to account for how states might influence the behavior of others, even reduce the threats they face in the international system, by leveraging institutional rules, by setting the policy agenda within international organizations, or by shaping other states' preferences so they align with your own. As we will see below, institutional rules have been used to constrain nuclear weapons proliferation, the militarization of space, and the use of excessive military force in wartime. The ability to set the agenda within international organizations has led to restrictions on the use of land mines that kill and maim innocent civilians, generated support for collective security initiatives against emerging threats, and stimulated action on health care crises like the AIDS epidemic and efforts to reduce greenhouse gas emissions. If it is possible to shape other states' preferences on important issues, it will be easier to convince them to exercise self-restraint on a range of dangerous actions, like the use of chemical or biological weapons, or to join global initiatives that serve a collective good, like a peacekeeping operation in a distant part of the world.

Nye's most important contribution to this topic is his concept of "soft power," which clearly is meant to capture sources of influence over others that do not depend on tangible hard power resources. In simple terms, a country's soft power is about its 
ability to attract others through its culture, its political values, its competence and accomplishments, and the perceived legitimacy of its behavior on the world stage. Attraction becomes a source of power if it allows that state to influence the decisions and actions of others without having to resort to threats or explicit offers of a payoff for cooperation. One interesting example of preference shaping and soft power in a military context is the practice of American service academies and war colleges opening student positions for cadets and officers from militaries around the world. One key objective is to shape their preferences for such values as civilian control of the armed forces, respect for human rights and the laws of armed conflict, and to cultivate general admiration for America that shapes the officers' behavior in the future so that it aligns with America's values and preferences.

In the next section, we turn to liberal international relations theory in practice and, by doing so, accept a challenge issued by John Mearsheimer (1994-1995), among the most prominent American realist scholars. Mearsheimer rejects the claim that liberal theory can reduce the dangers of military power in world politics. According to Mearsheimer, while liberal theory might provide a valid explanation for cooperation in issue areas such as trade and environmental protection, it has little to offer for states seeking a way to understand and pursue military security in an anarchic international system. The examples below might illustrate where Mearsheimer's critique falls short.

\section{Liberal International Relations Theory in Practice}

The liberal impulse in world politics surged in the aftermath of World War I, when President Woodrow Wilson became the most passionate voice arguing for the rejection of balance of power politics, which had been the basis of the international order since the emergence of the modern state system. In its place, he proposed a new liberal order based on several key features: 1) democratic governance within states to give voice to what he believed would be the natural interests of citizens of all countries in peace; 2) a system of arbitration of state conflicts to prevent the inevitable disputes from turning violent; and 3) a League of Nations embodying a system of collective security, in which all members would pledge to aid any other member that became the victim of aggression from those states that did not pursue peaceful conflict resolution (DiNunzio, 2006). But Wilson's vision never materialized.

Liberal theory met with serious setbacks between the world wars, as the Great Depression of the 1930s and the coming of World War II called into question its vision of what might be accomplished in world politics. Despite Wilson's leadership, the American Senate rejected membership in the League of Nations, the Great Depression produced a collapse of the global trade system, and the rise of authoritarian militarism in Germany, Italy, and Japan could not be contained by any notion of collective security.

The Great Depression served as a catalyst for an expansion of Japan's war with China in the early 1930s. Just a decade earlier, Japan pursued what they called 
Shidehara diplomacy, a policy of extensive trade to gain access to the resources necessary for industrial production and markets for their goods. The ultimate objective was to ensure that Japan sustained the economic growth necessary for investments in military power, and in turn, security and autonomy in a threatening international system. But they did it peacefully. When the Great Depression hit, the United States responded by raising tariff barriers on imported goods with the SmootHawley Act of 1930 to protect its own domestic manufacturing. With its continental scale, its rich natural resource base, and large population, American leaders decided they could weather this economic crisis best by relying primarily on their own territory. Great Britain followed the Americans' lead by creating the "imperial preference system" during the Ottawa conference of 1932, which provided low tariffs for products traded within the British Empire and among the Dominion countries, while raising barriers to goods from other parts of the world. Like America, Britain leveraged its expansive territorial control and access to meet the global trade crisis.

Among the great powers, Japan was the most vulnerable to this shock to global trade; it simply did not have a rich geographic base to fall back on. As a result, Japanese leaders concluded that violent imperial expansion was the only viable option for survival as an industrial power. Japan's war with China began with its invasion of Manchuria in 1931; it expanded its imperial war against China through the 1930s and eventually seized France's colonial possessions in Southeast Asia in 1940. The United States responded with increasingly tough economic sanctions that eventually included an embargo on American steel and oil imports, which was meant to compel Japan to withdraw its imperialist conquests. This simply fed a spiraling crisis and empowered militant voices in Japan calling for a final push to secure regional dominance across East Asia and the territory necessary for sustaining its economic and military power (Barnhart, 1987; Copeland, 2011; Iriye, 1990).

The coming of the second great power war in twenty years, and the emergence of the Cold War between the USA and the USSR after that war, led many in the field of international relations to decry the "utopianism," the "idealism," of early twentiethcentury liberal thought. But the tragedy of mass violence and the escalating security risks of this century continued to inspire liberal theorists and policymakers to pursue initiatives that would stabilize some of the most dangerous features of world politics. Instead of accepting perpetual, high-intensity competition and war as inevitable, many practitioners turned to the logic and instruments of liberal theory for solutions to the problems of competition, war, and general human suffering. And in the ensuing decades, even if liberal theory has not swept these problems away, it has helped dampen the risks, as some of the examples below illustrate.

The creation of the United Nations system, of course, is among the most ambitious postwar initiatives. Despite the failure of the League of Nations after World War I, the devastation of World War II motivated a strong demand for an international organization that could facilitate coordinated efforts to prevent war and pursue a range of liberal social and economic goals. Its relevance to the role of military force in world politics is anchored by the UN's founding document, which draws from the logic of both realism and liberalism. For example, following the liberal impulse to 
control violence and the logic of institutionalism, Chapter I of the Charter calls on member states to "refrain in their international relations from the threat or use of force against the territorial integrity or political independence of any state." Chapter VI of the UN Charter mandates the peaceful settlement of international disputes and has been used to authorize dozens of peacekeeping missions over the decades.

Chapter VI, Article 51, sets out the rules on the use of force specifically; no longer is the right to use force the unquestioned sovereign prerogative of any individual state, unless a state is acting in its inherent right to self-defense against aggression and there is no time to seek approval or assistance from the international community. In all other cases that fall short of immediate self-defense, the United Nations Security Council, under Chapter VII, is the only international organ that can approve the legitimate use of force against anything it declares to be a "threat to international peace and security."

The structure of the Security Council does acknowledge the realities of hard power in the international system (at least as it was perceived in 1945) when the five major allied powers of World War II - the United States, Great Britain, the Soviet Union, France, and China - were granted permanent membership and veto power over resolutions. But along with ten other member states that occupy regional seats on a rotating basis, the UN Security Council has no rival in terms of legitimating military force at the international level. While the goal was noble, power politics during the Cold War prevented the Security Council from playing the role intended at the founding. The first time Chapter VII of the Charter was actually used to authorize the use of "all necessary means" to turn back aggression was in November 1990 in response to Iraq's invasion of Kuwait (Quigley, 1992). Forty years earlier, in June 1950, the UN Security Council authorized member states to use force to restore international peace after the North Korean invasion of South Korea, but this vote was taken without the Soviet delegate attending the meeting.

Since then, the most important debate over the role of the UN in the security realm has concerned the question of state sovereignty and humanitarian crises that might generate strong pressure for international intervention. "Sovereignty," the foundational concept that organizes the very structure of the global political order, is itself the product of a historical moment of immense violence - the Thirty Years' War that raged across Europe in the early seventeenth century - and the effort of leaders in the peace to establish rules that would limit the prevalence of warfare. As an institution, the rules of sovereignty were meant to protect territorially defined states that had the right to be free from external interference within their borders, interference that often came in the form of violent intervention and coercion, and the obligation to respect this right for others.

Interestingly, the same institution meant to control foreign state interference in domestic affairs, and the inter-state violence it can produce, has in recent decades come into conflict with the broader liberal values that prioritize individual human rights and freedom from repression. As a result, liberalism has prompted a movement to restrict the protections of sovereignty for political and military leaders accused of gross human rights violations, particularly genocide, and to legitimate 
humanitarian military interventions meant to rescue populations suffering from the consequences of state failure even if they are not the direct victims of political repression (Power, 2003). Since the end of the Cold War, prominent cases of liberal interventionism, or at least demands for military intervention, have spanned the globe, to include among others, Somalia, Haiti, Bosnia, Rwanda, Kosovo, East Timor, the Democratic Republic of Congo, Liberia, Sierra Leone, Venezuela, Syria, Yemen, and Libya.

Despite its promise, the UN, like the League of Nations, has clearly fallen short of its founders' vision. In fact, realists point to the $\mathrm{UN}$ as an example of the continuing dominance of power politics that impede international cooperation. But better examples of liberal theory at work come in the form of the postwar international economic system and the European integration movement.

Even before WWII was won, allied governments were looking ahead to the postwar order. In 1944, economic planners met at Bretton Woods, in the American state of New Hampshire, to create a set of monetary rules and organizations that would foster free trade, economic development, and the stability of national currencies. It was inspired by one of the most important lessons of the inter-war period: Not only was the Great Depression of the 1930s, which brought mass unemployment, bank failures, plunging stock markets, and the collapse of international trade, a global economic catastrophe, the shock of this economic crisis also rippled into international security politics in dangerous ways. Postwar planners recognized that economic turmoil fed nationalist and militaristic ideologies in Europe, providing an opportunity for the Nazi Party in Germany to leverage domestic fears and frustrations to build popular support for its violent ambitions. So the goal of constructing a cooperative liberal trade and financial system after World War II was not merely to enhance economic prosperity, but it was essential for preventing a repeat of the devastating experience of the 1930s and early 1940s.

The Bretton Woods system created the International Bank for Reconstruction and Development, the forerunner of the World Bank, a global institution that supports economic development, and the International Monetary Fund, which helps control destabilizing fluctuations in the value of states' currencies. Two years after the war, a follow-on conference established the General Agreement on Tariffs and Trade, the forerunner to the current World Trade Organization (WTO), which not only created the rules for the open trade system, but it also created mechanisms for states to periodically update these rules for the increasingly complex global economy and to peacefully adjudicate economic disputes among them (Cohen, 1977; Dormael, 1978; Ikenberry, 2011; Maier, 1987).

While the Bretton Woods system was putting liberal principles to work for the global financial and trade order, within Europe and the trans-Atlantic community specifically an even more audacious scheme was launched to limit the scourge of great power conflict. The European integration movement in the years after World War II is often treated as merely an effort to build an effective alliance against the emerging Soviet threat. But as western political leaders looked ahead to the postwar period, the greatest threat many saw was that the cycle of war among European great powers would continue. Just as World War II followed World War I, the fear was that 
World War III was just another generation away once Germany had recovered from defeat.

In response to this fear, the European integration movement was a peace project. It was a conscious effort by Europeans, particularly the French visionary Jean Monnet, as well as American leaders, to dampen or eliminate the underlying causes of the fear, uncertainty, and perceptions of threat produced by international anarchy and extremist politics that in turn had produced hundreds of years of rivalry, arms races, shifting alliances, and war. While integration developed in fits and starts over the decades after World War II, this movement was the vehicle for solving the security dilemma among European states. Considering the history of Europe, which has been called the "cockpit" of repeated great power wars for centuries, the European integration movement is nothing short of revolutionary in world politics.

The overarching security logic that best describes the various aspects of European integration has been called "security binding," and binding is presented as a liberal alternative to traditional realist balancing logic. As a security scheme, balancing depends on the capacity to physically counter potential rivals. In contrast, binding is about bringing potential rivals together, integrating their political, economic, and defense relationships in ways that increase trust and produce the incentives for cooperation that come with mutual interdependence. G. John Ikenberry calls security binding "arguably the most important innovation in national security in the twentieth century" (Ikenberry, 2011, p. 183). A few specific policy initiatives help illustrate how it worked in practice.

In 1947, US Secretary of State George C. Marshall announced a large economic aid package for European states still suffering from the devastation of war and facing the risk that economic suffering could once again produce extremist political movements. "There can be no political stability and no assured peace," Marshall declared, until European recovery gained momentum. But this was no simple scheme for doling out aid packages to America's partners. Countries accepting support had to agree to a critical condition: They must collectively decide how every penny was to be spent across Europe, among friends and former enemies alike. The Organization for European Economic Cooperation (OEEC) was created to serve as an organizational vehicle for this task, and it embodied the shared interests and incentives for mutual gain made available by Marshall aid (Mastanduno, 1998).

An important European initiative that drew from the same liberal binding logic was the European Coal and Steel Community (ECSC), spearheaded by French Foreign Minister Robert Schuman in 1950. The ECSC integrated the coal and steel sectors of six Western European states. According to Schuman, "The pooling of coal and steel production," most importantly the industries of France and West Germany, "will change the destinies of those regions which have long been devoted to the manufacture of munitions of war, of which they have been the most constant victims" (European Union). And in the decades that followed, the ECSC and the OEEC were succeeded by new bodies that expanded and deepened the ties among European states, from the European Economic Community to the European Community, to the European Union today. 
One unusual example of security binding is the North Atlantic Treaty Organization (NATO), founded in 1949 in response to the threat posed by Soviet military forces in Central Europe and fears of the USSR's aggressive expansionist ambitions. NATO is a military alliance, so its core mission clearly falls within the balancing logic of realist theory. But its founders recognized that NATO had another purpose as well. It has also served as an organization that created an integrated defense relationship among former enemy states at a time of great uncertainty over whether Germany would pose the greatest threat in the years to come. Simply put, NATO solved the security problem for the West Germans themselves by binding them to the transatlantic community. This reduced the likelihood that Germany would again turn to militarism to face the pressures of an anarchic international system and the hard reality of its geographic vulnerability as a major power in the center of the European continent, facing potential threats from west and east. As Ikenberry has noted, "nowhere in the negotiations over the treaty was there an intention of creating a large transatlantic NATO bureaucracy or an integrated military establishment headed by an American general.” Instead, American leaders believed NATO's purpose, like Marshall Plan aid, "was to lend support to European steps to build stronger economic, political, and security ties within Europe itself" (Ikenberry, 2000, p. 197; Schwabe, 1995).

\section{Summary: Liberal International Relations Theory in an Era of Renewed Great Power Competition}

For nearly two decades after the end of the Cold War in the late 1980s and the collapse of the Soviet Union in 1991, the champions of the liberal vision for world politics saw great promise in the democratization of former authoritarian states and the expansion of economic openness and international institutions around the world. President George H. W. Bush heralded the arrival of a New World Order marked by cooperation and collective action to defeat aggression and alleviate human suffering. British Prime Minister Margaret Thatcher was an early advocate of democracy as a source of peace. President Bill Clinton's first National Security Strategy called for "enlargement" of the liberal "zone of peace" through NATO and European Union expansion, focused on creating a "Europe whole and free" that included a new institutionalized relationship with a democratizing and reformist Russia. The meteoric rise of China's economy, made possible by its willingness to leverage the benefits of the open liberal trade system, was a promising sign that as it became more prosperous and more powerful, China would become a "responsible stakeholder" in a global order defined by liberal principles (Bush 1993; Lake 1993; Brands \& Cooper, 2019).

In the 2020s, however, political leaders and scholars around the world assert that a new era of great power competition has arrived, and realist theory once again seems to provide insight into worrisome developments in the international system. The zone of liberal peace across Europe now spans the broadest geographic scope in its history, but realists argue that NATO and EU expansion has also triggered 
Russian fears of encroachment. China has grown prosperous, and its dependence on foreign markets and investment opportunities will likely act as a constraint on dangerous behavior, but its increasing strength has also increased its willingness to challenge the United States and its allies in East Asia and the Western Pacific (Mearsheimer, 2014). Renewed interest in nuclear weapons as a tool of great power competition and the contest over China's territorial claims in the South China Sea provide dangerous flashpoints. Perhaps there is a role for liberal logic to keep a cap on the level of risk we face.

One important example deserves consideration. The logic of Neoliberal Institutionalism still has policy relevance for controlling nuclear weapons in the twentyfirst century, and while not perfect, arms control initiatives during the Cold War demonstrate its feasibility. By the early 1960s, the United States and the Soviet Union, mortal enemies trapped in a spiraling arms race, in a rational assessment of their own security interests, recognized that they would be more secure if they cooperated to limit the many ways that nuclear weapons and weapons testing can proliferate. The first breakthrough was the 1963 Partial Test Ban Treaty, which to this day prohibits all testing in the atmosphere, in outer space, and in the ocean, thus limiting the ecological and health risks produced by nuclear detonations. This was followed in the late 1960s by the Nuclear Non-Proliferation Treaty (NPT), which remains the most important institution that legitimizes international efforts to prevent the spread of nuclear weapons to states beyond the original five that had nuclear weapons when the treaty was opened for signature (the United States, the Soviet Union/Russia, Great Britain, France, and China). While a skeptic can point to the self-serving nature of the NPT, which did not place any real disarmament demands on the existing nuclear weapons states, it continues to underpin the work of organizations like the International Atomic Energy Agency which monitors, inspects, and reports on nuclear activities by other states, while the treaty provides a legal and normative basis for the United Nations Security Council to hold states like North Korea accountable for violating its rules.

Beginning in the early 1970s, as the nuclear arms race between the United States and Soviet Union reached a frenetic pace, the Cold War rivals themselves turned to arms control to cap the most dangerous advancements in their arsenals. What followed was a series of negotiations and treaties that, while not ending the Cold War or eliminating competition in the nuclear weapons realm, helped stabilize deterrence and reduced the intensity of the threat. The key treaties included the Anti-Ballistic Missile Treaty (ABM) and the Strategic Arms Limitation Treaty (SALT I) of 1972, the Intermediate Range Nuclear Forces Treaty (INF) of 1987, which for the first time eliminated an entire class of weapons, and the Strategic Arms Reduction Treaty (START) of 1991 that actually reduced strategic arsenals by 80 percent (Arms Control Association).

The post-Cold War arms control record is mixed, to be sure. The United States withdrew from the ABM treaty in 2002, and it withdrew from the INF treaty in 2018, claiming that Russia was developing a new missile that should be prohibited under INF rules and that China, which is not party to the treaty, gains an unfair advantage while it fields weapons that should be banned. But more recently, even as serious 
tensions continue to grow between Russia and the United States, these antagonists have renewed the New START Agreement, which first went into effect in 2011 to cap the total number of deployed land- and submarine-based missiles and heavy bombers, as well as the number of warheads allowed for each launch platform.

It is interesting to note that all nuclear weapon states (except for North Korea) are following the rules of another post-Cold War global arms control agreement, the Comprehensive Test Ban Treaty (CTBT), even though it is not officially in force. This includes major states that are not signatories to the treaty (like the United States) or have not ratified it (like Russia and China). It seems that self-interest and the fear of reciprocity, the core logic of liberal institutionalism, are at work bringing restraint in the testing of nuclear weapons, even though in a formal sense they are not obliged to comply. The United States first signed the CTBT under President Clinton in 1996, but it failed to gain ratification in the US Senate. President George W. Bush then removed America as a signatory. But despite pressure from scientists and administrators responsible for America's nuclear infrastructure, who have persistently argued in favor of renewed testing to check the safety and reliability of its weapons, every president since has rejected this advice. The United States has not conducted a nuclear test since 1992. Russia conducted its last test in 1990, China in 1996.

While direct evidence is hard to uncover, it is reasonable to hypothesize that each major power is holding back because its leaders know that as soon as any of them conducts a test, the others will follow with their own tests, ultimately making all nuclear weapon states less secure. Perhaps there are other issue areas in a world of great power rivalries that are still ripe for liberal rule-governed behavior in which states recognize the dangers of unfettered competition, that mutual interests might exist, and that self-restraint to hold others in check is a viable option as states seek security, prosperity, and a stable future.

\section{References}

Arms Control Association. Arms control treaties. Retrieved from https://www.armscontrol.org/ treaties.

Axelrod, R. (1984). The evolution of cooperation. New York: Basic Books.

Barnhart, M. (1987). Japan prepares for total war: The search for economic security, 1919-41. Ithaca: Cornell University Press.

Brands, H., \& Cooper, Z. (2019). After the responsible stakeholder, What? debating America's China strategy. Texas National Security Review, 2(2) Retrieved from https://nsr.org/2019/02/ after-the-responsible-stakeholder-what-debating-americas-china-strategy-2/.

Brown, M. E., Lynn-Jones, S. M., \& Miller, S. E. (Eds.). (1996). Debating the democratic peace. Cambridge: MIT Press.

Bush, G. H. W. (1993). Address to the cadets at the United States Military Academy.

Carr, E. H. (1964). The twenty years' crisis: 1919-1939. New York: Harper and Row.

Cohen, B. (1977). Organizing the world's money: The political economy of international monetary relations. New York: Basic Books.

Copeland, D. C. (1996). Economic interdependence and war: A theory of trade expectations. International Security, 20(4), 5-41.

Copeland, D. C. (2011). A tragic choice: Japanese preventive motivations and the origins of the pacific war. International Interactions, 37(1), 116-126. 
Deudney, D. (2007). Bounding power: Republican security theory from the polis to the global village. Princeton: Princeton University Press.

DiNunzio, M. R. (Ed.). (2006). Woodrow wilson: Essential writings and speeches of the scholarpresident. New York: New York University Press.

Dormael, A. V. (1978). Bretton woods: Birth of a monetary system. London: Macmillan.

Doyle, M. W. (1983a). Kant, liberal legacies, and foreign affairs. Philosophy \& Public Affairs, 12(3), 205-235.

Doyle, M. W. (1983b). Kant, liberal legacies, and foreign affairs, Part 2. Philosophy \& Public Affairs, 12(4), 323-353.

Doyle, M. W. (1986). Liberalism and world politics. American Political Science Review, 80(4), $1151-1169$.

European Union. Schuman declaration. https://europa.eu/european-union/about-eu/symbols/ europe-day/schuman-declaration_en.

Hirschman, A. O. (1977). The passions and the interests: Political arguments for capitalism before its triumph. Princeton: Princeton University Press.

Ikenberry, G. J. (2000). After victory: Institutions, strategic restraint, and the rebuilding of order after major wars. Princeton: Princeton University Press.

Ikenberry, G. J. (2008). The rise of China and the future of the west: Can the liberal system survive? Foreign Affairs, 87(1), 23-37.

Ikenberry, G. J. (2011). Liberal leviathan: The Origins, crisis, and transformation of American world order. Princeton: Princeton University Press.

Iriye, A. (1990). After imperialism: The search for a new order in the far east, 1921-1931. Chicago: University of Chicago Press.

Jay, J. (1787). Federalist papers. Nos. 3, 5.

Kant, I. (1970). Perpetual peace: A philosophical sketch. H. Reiss (Ed.). H. B. Nisbet (Trans.). Cambridge: Cambridge University Press.

Keohane, R. O. (1983). After hegemony: Cooperation and discord in the world political economy. Princeton: Princeton University Press.

Keohane, R. O. (1990). International liberalism reconsidered. In J. Dunn (Ed.), The economic limitations of modern politics. Cambridge: Cambridge University Press.

Keohane, R. O. (1998). International institutions: Can interdependence work? Foreign Policy, 110, 82-91.

Keohane, R. O., \& Nye, J. (2012). Power and interdependence. Boston: Longman.

Lake, A. (1993). From engagement to enlargement. Address at the Johns Hopkins University School of Advanced International Studies.

Madison, J. (1787). Federalist papers. Nos. 10, 37, 46, 51.

Maier, C. (1987). In search of stability: Explorations in historical political economy. New York: Cambridge University Press.

Mastanduno, M. (1998). Economics and security in statecraft and scholarship. International Organization, 52(4), 825-854.

Mearsheimer, J. J. (1994-1995). The false promise of international institutions. International Security, 19(3), 5-49.

Mearsheimer, J. J. (2014). The tragedy of great power politics. New York: W. W. Norton.

Moravcsik, A. (2008). The new liberalism. In C. Reus-Smit \& D. Snidal (Eds.), The oxford handbook of international relations. Oxford: Oxford University Press.

North, D. C. (1990). Institutions, institutional change and economic performance. Cambridge: Cambridge University Press.

Nye, J. (2011). The future of power. New York: Public Affairs.

Power, S. (2003). A problem from hell: America and the age of genocide. New York: Basic Books.

Quigley, J. (1992). The United States and the United Nations in the Persian gulf war: New order or disorder. Cornell International Law Journal, 25(1), 25-49.

Rønnfeldt, C. F. (2021). International relations and military sciences. In A. M. Sookermany (Ed.), Handbook of military sciences (p. Forthcoming). Cham: Springer. 
Rosecrance, R. (1986). The rise of the trading state. New York: Basic Books.

Russett, B. (1993). Grasping the democratic peace. Princeton: Princeton University Press.

Schelling, T. (1977). Arms and influence. New York: Praeger.

Schmidt, B. (2021). Realist international relations theory and the military. In A. M. Sookermany (Ed.), Handbook of military sciences (p. forthcoming). Cham: Springer.

Schwabe, K. (1995). The United States and European Integration, 1947-57. In C. Wurm (Ed.), Western Europe and Germany, 1945-1960. New York: Oxford University Press.

Silverstone, S. A. (2004). Divided union: The politics of war in the early American Republic. Ithaca: Cornell University Press.

Sookermany, A. M. (2021). Philosophy of military sciences. In A. M. Sookermany (Ed.), Handbook of military sciences (p. Forthcoming). Cham: Springer.

Tang, Y. (2021). How the WTO changed China. Foreign Affairs, 100(2), 90-103.

Wilson, W. (1923). Woodrow Wilson's case for the league of nations. London: Oxford University Press.

Open Access This chapter is licensed under the terms of the Creative Commons Attribution 4.0 International License (http://creativecommons.org/licenses/by/4.0/), which permits use, sharing, adaptation, distribution and reproduction in any medium or format, as long as you give appropriate credit to the original author(s) and the source, provide a link to the Creative Commons license and indicate if changes were made.

The images or other third party material in this chapter are included in the chapter's Creative Commons license, unless indicated otherwise in a credit line to the material. If material is not included in the chapter's Creative Commons license and your intended use is not permitted by statutory regulation or exceeds the permitted use, you will need to obtain permission directly from the copyright holder.

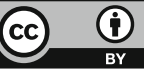

